\title{
Topological analysis of local heteropolyhedral substitutions in the eudialyte-related structures
}

\author{
Sergey Aksenov $^{1,2}$, Natalia Kabanova ${ }^{1,3}$, Nikita Chukanov ${ }^{4,5}$, Vladislav Blatov ${ }^{3}$, Sergey Krivovichev ${ }^{6,7}$ \\ ${ }^{1}$ Laboratory of Nature-Inspired Technologies and Environmental Safety of the Arctic, Kola Science Centre, \\ Russian Academy of Sciences, Apatity, Russian Federation; \\ ${ }^{2}$ Geological Institute, Kola Science Centre, Russian Academy of Sciences, Apatity, Russian Federation; \\ ${ }^{3}$ Samara Center for Theoretical Materials Science, Samara State Technical University, Samara, Russian Federation; \\ ${ }^{4}$ Institute of Problems of Chemical Physics, Russian Academy of Sciences, Chernogolovka, Russian Federation; \\ ${ }^{5}$ Faculty of Geology, Moscow State University, Vorobievy Gory, Moscow, Russian Federation; \\ ${ }^{6}$ Nanomaterials Research Centre, Kola Science Center, Russian Academy of Sciences, Apatity, Russian Federation; \\ ${ }^{7}$ Department of Crystallography, Institute of Earth Sciences, St Petersburg State University, St Petersburg, Russian Federation;
}

$$
\text { aks.crys@gmail.com }
$$

Eudialyte-group minerals (EGMs) are of a scientific and industrial interest as important concentrators of rare and strategic elements (mainly, $\mathrm{Zr}$ and REE) in agpaitic alkaline rocks. The general crystal chemical formula of EGMs is $\left[N(1)_{3} N(2)_{3} N(3)_{3} N(4)_{3} N(5)_{3}\right]\left\{M(1)_{6} M(2)_{3} M(3) M(4) Z_{3}\left(\mathrm{Si}_{9} \mathrm{O}_{27-3 x}(\mathrm{OH})_{3 x}\right)_{2}\left(\mathrm{Si}_{3} \mathrm{O}_{9}\right)_{2} \emptyset_{0-6}\right\} X(1) X(2) \quad$ where $M(1) \quad={ }^{\mathrm{VI}} \mathrm{Ca},{ }^{\mathrm{VI}} \mathrm{Mn}^{2+},{ }^{\mathrm{VI}} R E E$,

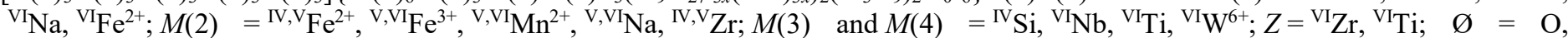
$\mathrm{OH} ; N(1)-N(5)$ are extra-framework cations $\left(\mathrm{Na}, \mathrm{H}_{3} \mathrm{O}^{+}, \mathrm{K}, \mathrm{Sr}, R E E, \mathrm{Ba}, \mathrm{Mn}^{2+}, \mathrm{Ca}\right)$ or $\mathrm{H}_{2} \mathrm{O} ; X(1)$ and $X(2)$ are extra-framework water molecules, halide $\left(\mathrm{Cl}^{-}, \mathrm{F}^{-}\right)$and chalcogenide $\left(\mathrm{S}^{2-}\right)$ anions, and anionic groups $\left(\mathrm{CO}_{3}{ }^{2-}, \mathrm{SO}_{4}{ }^{2-}\right) ; x=0-1$ (Rastsvetaeva \& Chukanov, 2012).

The crystal structure of EGMs is based on a heteropolyhedral framework (Chukanov et al., 2004) which makes these minerals similar to zeolite-like materials and molecular sieves. The first topological analysis of the eudialyte-type structures (eudialyte, kentbrooksite, oneillite, and khomyakovite) was performed using the approach of coordination sequences $\left\{N_{k}\right\}(k=1-12)$, using the representation of crystal structure as a finite 'reduced' graph (Ilyushin \& Blatov, 2002). As an invariant of the eudialyte-type structure and its derivatives the $M T$-layer $\left[\mathrm{Zr}_{3} \mathrm{Si}_{24} \mathrm{O}_{72}\right]_{\infty \infty \infty}$ (PBU: primary building unit, an elementary component of an $M T$-framework) was chosen.

Topological analysis of the heteropolyhedral $M T$-framework in the eudialyte-type structure and its derivatives was performed based on a natural tiling (Blatov et al., 2007) (partition of the crystal space by the smallest cage-like units) analysis of the 3D cation nets using the ToposPro software (Blatov et al., 2014). According to the modern topological classification, it is necessary to use the standard representation to determine the topological type of the net. For the topological analysis carried out in this work, atomic nets for each of the 12 structure types were simplified and the corresponding underlying nets, which characterize the connectivity of the primary structural units as well as their point symbols, were obtained. The 0-1-2-free representation was used for topological analysis of cages within the tiling approach because it represented the cages in more detail. To analyze the migration paths of sodium cations in these structures, the Voronoi method was used.

The parental eudialyte-type $M T$-framework is formed by isolated $Z_{0}$ octahedra, six-membered $\left[M(1)_{6} \mathrm{O}_{24}\right]$ ring of edgeshared $M(1) \mathrm{O}_{6}$ octahedra, and two types of rings of tretrahedra, $\left[\mathrm{Si}_{3} \mathrm{O}_{9}\right]$ and $\left[\mathrm{Si}_{9} \mathrm{O}_{27}\right]$. Different occupancies of additional $M(2), M(3)$, and $M(4)$ sites with variable coordination numbers by $Q, T^{*}$, and $M^{*}$ cations, respectively, result in 12 types of the $M T$-framework. Corresponding point symbols for the cationic 3D-nets of the $M T$-frameworks as well as tiles' sequences have been calculated.

Based on the results of natural tilings calculations as well as theoretical analysis of migration paths, it was found that $\mathrm{Na}^{+}$ions can migrate through six- and seven-membered rings, while all other rings are too small. In eight types of the $M T$-frameworks, $\mathrm{Na}^{+}$-ion migration and diffusion is possible at standard temperature and pressure, while in four other types cages are connected by narrow gaps and, as a result, the $\mathrm{Na}^{+}$diffusion in them is complicated at ambient conditions but may be possible either at higher temperatures or under mild geological conditions during long times. This conclusion is in a good agreement with numerous examples of the transformation of initial EGMs into their hydrated Na-deficient counterparts as a result of natural processes of sodium leaching and hydrolysis under hydrothermal conditions.

The relationships between heteropolyhedral substitutions and topological features of the derivative framework structures have been also discussed for alluaudite supergroup (Aksenov et al., 2021) minerals and related synthetic compounds. However, in the case of eudialyte-type structures such relationships look more complicated because of multiple variants of their derivative structures. Moreover, in the case of so-called "megaeudialytes" (Rastsvetaeva et al., 2012), i.e. EGMs which are characterized by modular structures and doubling of the $c$ parameter $(c \sim 60 \AA)$, different modules regularly alternating in the structure can represent different types of the framework, which increases the amount of topological variations. Similar influence of modularity on the topological features of zirconium silicates have been described for the lovozerite-type structures (Pekov et al., 2009), where different ways of stacking of the lovozerite modules define the unit cell parameters, symmetry, and topology of the derivative structures (Krivovichev, 2015).

Acta Cryst. (2021), A77, C557-C558 
Aksenov, S. M., Yamnova, N. A., Kabanova, N. A., Volkov, A. S., Gurbanova, O. A., Deyneko, D. V., Dimitrova, O. V. \& Krivovichev, S. V. (2021). Crystals. 11, 237.

Blatov, V. A., Delgado-Friedrichs, O., O’Keeffe, M. \& Proserpio, D. M. (2007). Acta Crystallogr. Sect. A Found. Crystallogr. 63, $418-425$.

Blatov, V. A., Shevchenko, A. P. \& Proserpio, D. M. (2014). Cryst. Growth Des. 14, 3576-3586.

Chukanov, N. V, Pekov, I. V \& Rastsvetaeva, R. K. (2004). Russ. Chem. Rev. 73, 205-223.

Ilyushin, G. D. \& Blatov, V. A. (2002). Acta Crystallogr. Sect. B Struct. Sci. 58, 198-218.

Krivovichev, S. V. (2015). Proc. Steklov Inst. Math. 288, 105-116.

Pekov, I. V., Krivovichev, S. V., Zolotarev, A. A., Yakovenchuk, V. N., Armbruster, T. \& Pakhomovsky, Y. A. (2009). Eur. J. Mineral. 21, 10611071.

Rastsvetaeva, R. K. \& Chukanov, N. V. (2012). Geol. Ore Depos. 54, 487-497.

Rastsvetaeva, R. K., Chukanov, N. V. \& Aksenov, S. M. (2012). Minerals of Eudialyte Group: Crystal Chemistry, Properties, Genesis Nizhniy Novgorod: University of Nizhni Novgorod.

Keywords: eudialyte group; mixed frameworks, ion migration; topology; isomorphism; zirconosilicates

This work was financially supported by the Russian Science Foundation, project No. 20-77-10065, Ministry of Education and Science of the Russian Federation for financial support within grant No. 0778-2020-0005, and state task, state registration number AAAAA19-119092390076-7. 